\title{
Design and Implementation of Geographic Information Systems of Poor Households on Web Based in Ketapang Regency
}

\author{
Muhammad Azhar Irwansyah ${ }^{1}$ and Hendro ${ }^{2}$ \\ ${ }^{1,2}$ Department of Engineering, the University of Tanjungpura, Pontianak, Indonesia \\ E-mail: ${ }^{1}$ irwansyah.azhar@gmail.com
}

\begin{abstract}
Poverty is a complex phenomenon and multidimensional issue. Ketapang regency breadth and characteristics of different poverty require different strategies to handle another kind of poverty. The poverty areas in Ketapang District, which generally are in rural and isolated areas with limited accessibility. The decreasing of poverty strategies which has been done is more sectoral approach and does not provide optimal results, while the action on the field tend to be less in favor and unusual according to the ability of the main citizen. Poverty alleviation programs will run properly, if a local government has datas on poor households those are accurate and up-to-date, so that is necessary for Geographic Information System WebBased Poor Households in Ketapang that the program will be given to poor households to be right on target.
\end{abstract}

Keywords: Poverty, Poverty Alleviation, Geographic Information Systems, Web.

\section{INTRODUCTION}

One of the goals of national development is to improve the performance of the economy to be able to address the problem of poverty, create jobs, increase the economic growth and able to make a decent life together. One of the goals of national development is poverty reduction. Poverty is one of the problems in the economy, so that must be solved or at least reduced. Therefore, efforts to alleviate poverty have to be comprehensive, covering various aspects of community life and implemented in an integrated manner. Poor Families based on data collection conducted by the Central Bureau of Statistics Ketapang District, Ketapang district showed that the number of poor households is 33273 households or 34.32 percent and the number of poor people 141743 inhabitants or 35.75 percent. The unsolve problem of poverty, encouraging our thought that a new strategy of poverty reduction which is more touching to the root causes of poverty is needed. Ketapang regency is concentrated in rural areas who are in the field of agricultural and plantation businesses while in other economic activities such as trade and services, as well as industrial and construction figures the poverty is relatively low.
Conditions of poor households in Ketapang District is faced with the problem of low quality of human resources, lack of land ownership, the number of households that do not have the assets, the limited alternative employment, yet insufficient public services, lumbung poverty degradation of natural resources and the environment, weak institutions and community organizations, and the helplessness in determining the price of the product.

Inability conditions and limitations of poor people in Ketapang regency led them in idle condition. In an effort to reduce the number of poor people in Ketapang District, the government has undertaken various programs and activities targeted at the poor. In an effort to reduce the life burden of the poor, especially in fulling the basic needs of poor rice has channeled aid, scholarships, revolving fund program. In the health sector the government provides health cards or JAMKESNAS that aims to reduce the burden of health care costs and have been distributed to the poor population as well as other assistance programs. Poverty reduction is a policy that should be consistently carried out by the government.

Poverty reduction as a form of development policy is the responsibility of all elements of the 
nation. This is realized by the fact that the financial capacity of the $g$ overnment to fund the implementation of poverty reduction policies are very limited. Therefore we need an understanding of the strategic role that should be done by governments. The strategic role of the government should be done within the boundaries of where government policy is being implemented and will actually be beneficial for the poor broadly and more specifically the benefits for communities and poor families. Poverty alleviation programs will run properly, if a local government has accurate and upto-date data on poor households.

The key word is the availability of good data of poor households will either be the database poverty. The approach taken is called the mapping of poverty (poverty mapping) to include web-based geographic elements that correlate with indicators of poverty based on analysis of a small area (small area analysis) or lower administrative levels. Involvement of the lowest governance (headman / village head) as well as an arm of government that is RT / RW is needed for the process of data collecting and updating of the population in addition to its oversight function. Community participation can be increased because the data and the existence of poor people dwelling accessible to the general public.

The involvement of the community is because of the assumption that they are the actors in the field most know the socio-economic condition of the people who are in their environment. Community elements that are closest to the citizens as well as officials that connects between citizens and government officials. The approach which is taken by the government in the form of a participatory approach (bottom-up), as a form of active involvement as well as the division of roles and responsibilities among stakeholders. By knowing the information, society is expected to be able to grow a sense of empathy, concern, and desire to help the poor especially those near his residence, web-based geographic information system that was built is expected to reduce the data manipulation of the poor so that helps the government in the eradication program appropriate poverty.

\section{RESEARCH METHODS}

There are 7 types of methods used in this paper. The first is a study of the literature was conducted to understand the related materials from some of the literature. The second is that data collection is done by taking the data from the relevant Department in Ketapang district and site survey of the poor. The third is the conceptual design of the system to be built in the form of design data flow diagram (DFD) system and entity relationship diagram (ERD), designing algorithms for statistical analysis of poverty in a region and the planning system testing methods. The fourth is the design of a prototype system which is an implementation of the third step in the application form. The fifth is the testing and validation of systems, testing is done using the Black Box. Besides testing, the suitability of information search results by search criteria. The sixth is the analysis of the test results, the analysis carried out in the testing and validation phase to determine the characteristics of the system and identify if there are inconsistencies in the system. Seventh is the conclusion which is formulated by the testing that has been done.

\section{SYSTEM ANALISIS}

\subsection{Architectural Design System}

The system was built consisting of a web-based application and has three types of users.

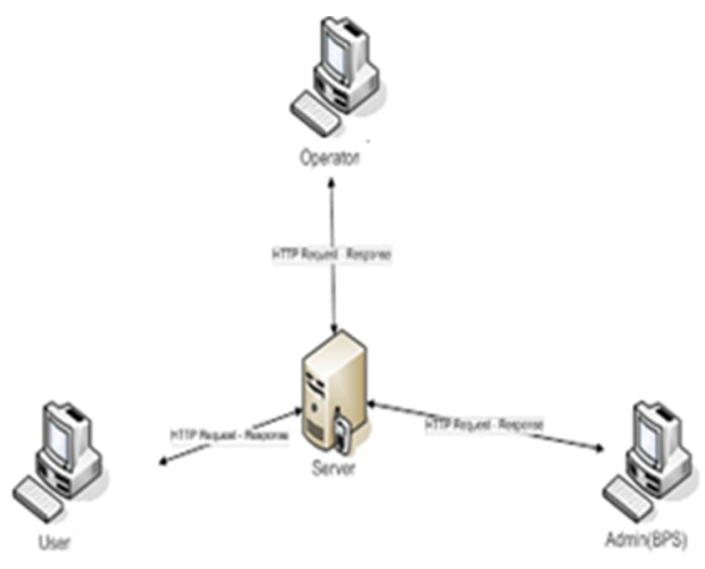

Fig. 1. The architectural design of the poor mapping applications.

Associated with server applications through the Internet. The application is built involves three types of users:

1) Applications built for the BPS (first level users), have full access to the system. This party has all the right to be able to perform additional updates or change the data of the poor exist on the server in accordance with the existing data.

2) Applications built for the Department Related (second level user), have limited access to the system. The parties have the 
right to be able to perform additional data for program assistance or changing existing data on the server according to the official use. In addition, the parties can also analyze existing data for consideration in making new policies on the poor households.

3) Applications which is built for the general public (third level users), have limited access rights to the system. This party can only access or search for information about the poor people who exist on the system.

\subsection{Designing Correlation Between Tables}

The tables in the geographic information system mapping of the poor has a relation to one another. Linkages and correlation between the tables with other tables shown in Figure 2:

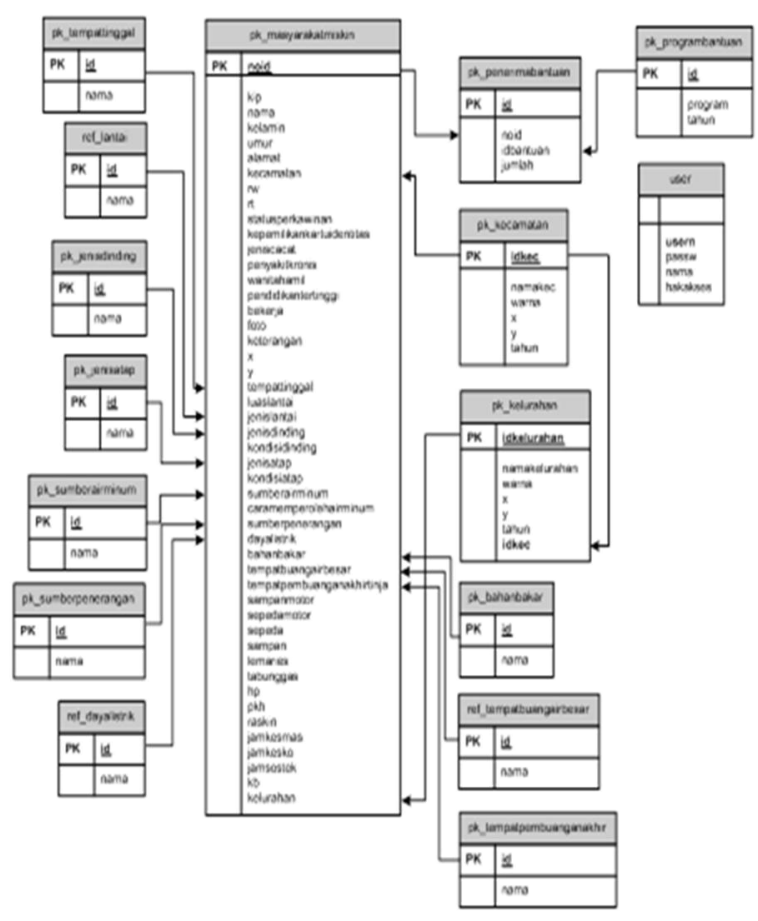

Fig. 2. Correlation between tables

\section{DESIGN RESULTS}

\subsection{Main Form}

The main form is the form that contains the menus to be accessed by the admin. Main form results interface design can be seen in figure 3 below.

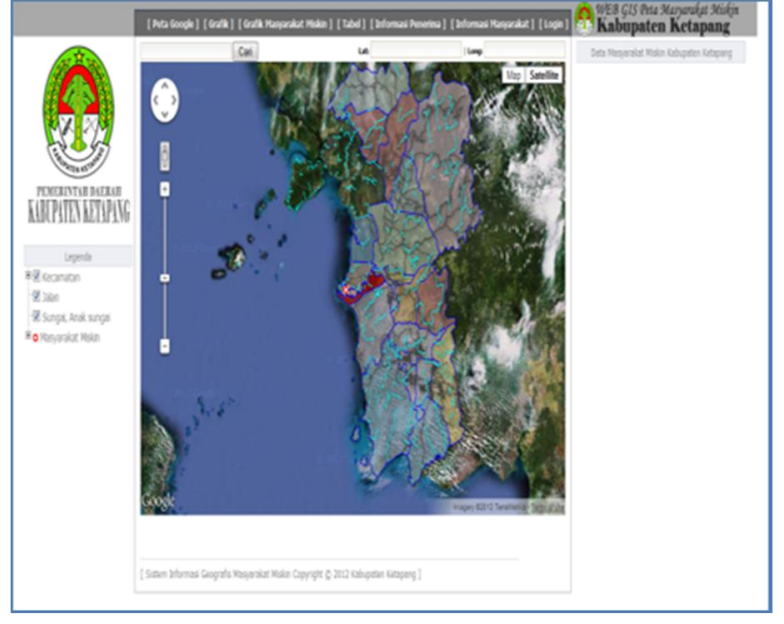

Fig. 3.Main Form

\subsubsection{Submenu Data Input}

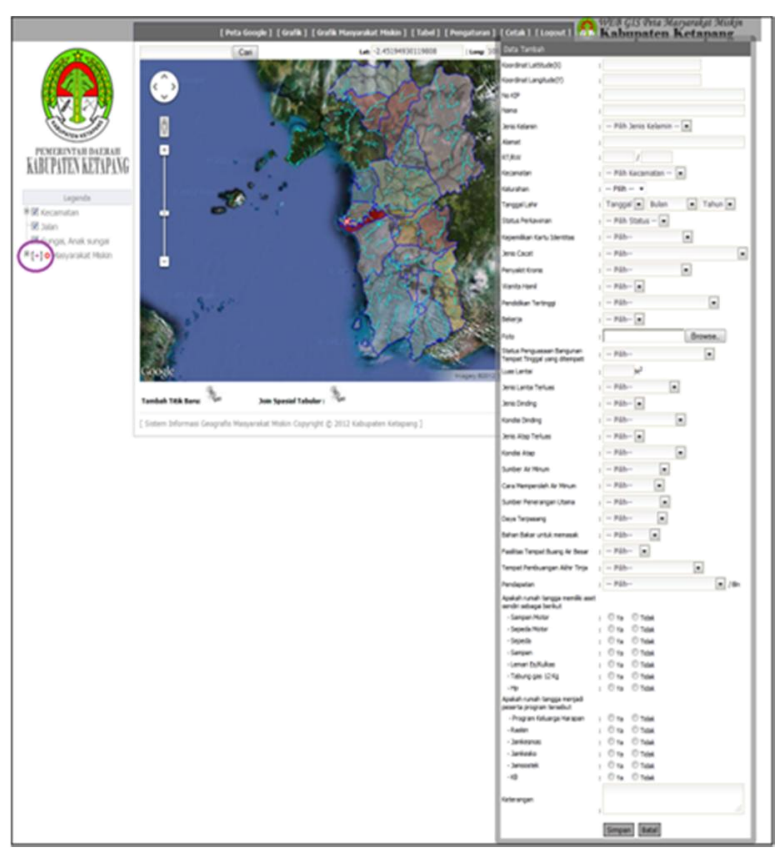

Fig. 4. Input data Menu

Data input menu is used to enter data on the poor which consists of several data. Admin should include complete data, because the system will give a message that no data has not been charged. Because no kip is the primary key, then it should not be the same no kip, so that the system will give

a message if no admins enter kip which have been registered. When all the data has been loaded and no kip who entered never registered before, then the system will confirm that the data has been saved. 


\subsubsection{Table Menu}

Table menu is used to display all data of the poor. In addition to the table menu, the admin can modify, delete, and view the location and detailed data of the poor. Interface design outcomes admin menu with submenu table can be seen in Figure 5 and Figure 6 below

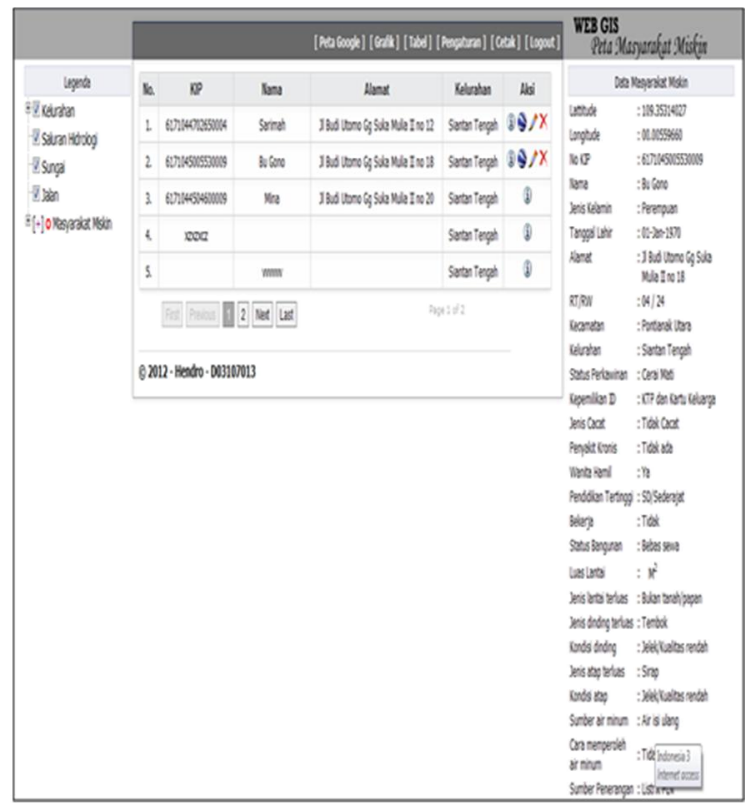

Fig. 5. Menu table data of the poor

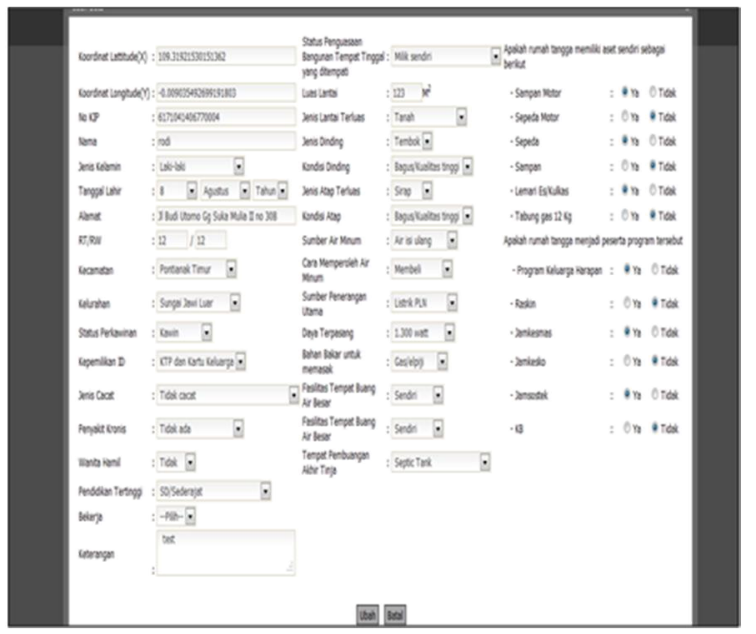

Fig. 6. Interface to Edit Data Submenu Table

\subsubsection{Grafic Menu}

Menu is used to view the graph chart principal household information on each household. The menu consists of a graph with fourteen graphs consisting of residential buildings mastery charts, graphs use the widest wall types, roof types widest use of graphs, charts source of drinking water, the main source of illumination charts, graphs of energy for cooking, landfills charts, graphs widest use of floor types, wall graphics conditions, the condition of the roof charts, graphs obtained water way, the electrical power used graphs, charts and graphs chapter facility assets. Graphic menu interface design results can be seen in Figure 7.

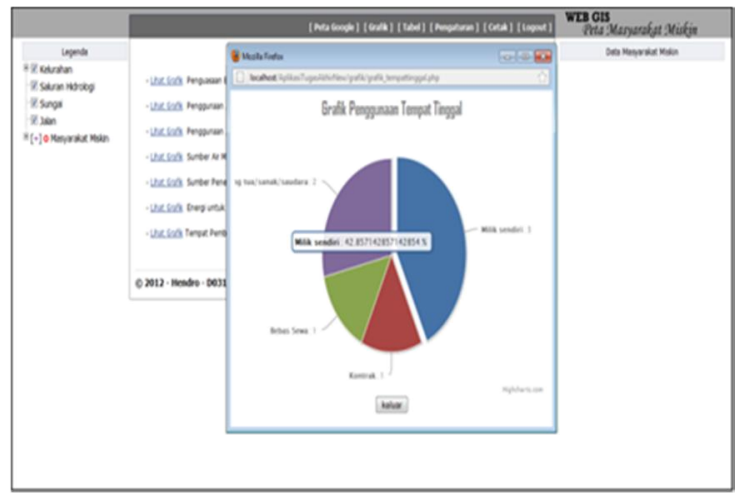

Fig. 7. Menu Chart

\subsubsection{Print Menu}

Printing Menu is used to print the data recap of the poor which consists of the introduction of data points, the data subject and the data of household socio-economic information berdasarkantahun household, which is accepted by district and help the poor. Print menu interface design results can be seen in Figure 8.

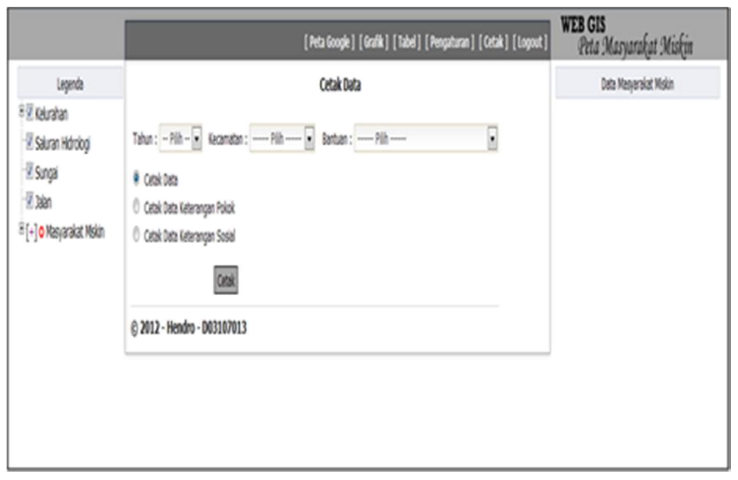

Fig. 8. Print Menu Interface

In AODV, broadcasted RREQ packet is received by all neighboring nodes. If any neighboring node is not available for some reason like link broken, low battery or congestion then it will send an "E 
5

\section{CONCLUSIONS AND SUGGESTIONS}

Based on the analysis and testing of the Geographic Information System Web-Based Mapping the Poor concluded that:

1) System can help manage data location (geographic) place to live and the poor in the form of data map with good accuracy and displays information about the support of the poor city of Pontianak.

2) Assessment by respondents Central Bureau of Statistics and Pontianak City Health Office, this application can be used to display and monitor the development of the poor people of the city of Pontianak so that the information can be advocates for policies related agencies to provide assistance in alleviating poor society of Pontianak.

\subsection{Suggestions}

Order data is always continuous, village poverty Teams should be formed consisting of relevant agencies that support programs of both central and regional government for the poor to be right on target.

\section{REFERENCES}

[1] Alatas, Vivi. 2007. "How many poor people in Indonesia?”. Tempo Magazine No. 20/VII/Jan, Jakarta, 2007, pp. 16-22.

[2] Ariani Sukamto, Rosa. 2009. "Black-Box Testing". February 19, 2012. http://www.gangsir.com/download/6-BlackBoxTesting.pdf.

[3] Central Statistics Agency (BPS), 2008. Analysis and Calculation of Poverty Level's 2008. Jakarta.

[4] Central Bureau of Statistics. 2010. Population Data. March 7, 2011. http://www.bps.go.id/hasilSP2010/kalbar/6171. pdf

[5] Chriswardani, Suryawati. Understanding the Multidimensional Poverty. http://www.jmpkonline.net/files/chriswaardani mknew.pdf.

[6] Hendraputra, A.; Pratondo, A.; Wijaya, D.; Darwiyanto, E.; Nugroho, E., and Kusuma, G. , 2009. Information Systems Quality Assurance. Bandung: Telkom
[7] Polytechnic.Myers, Glenford J. 2004. The Art of Software Testing, Second Edition. New Jersey: John Wiley \& Sons, Inc.

[8] Nasikun. , 2001. Issues and Policies for Poverty Reduction. Yogyakarta: Gadjah Mada University.

[9] Prahasta, Eddy. , 2001. Basic concepts of Geographic Information Systems. CV. Informatics, Bandung.

[10] Sholva, Yus. , 2009. Spatial Decision Support Systems to Support Poverty Reduction Through Participation of Urban Community and Participation Community RT/RW board as an extension of Government's Hands. $142 \mathrm{a} / \mathrm{H} 22.9 / \mathrm{PL} / 2009$, Final Report of the National Strategic Research 2009 bacth I, Pontianak.

[11] Sianturi, G. 2003. "Exit Strategy" Proverty, www.gizi.net.

[12] SMERU. 2008. The Poverty Map of Indonesia: Genesis and Significance, SMERU Newsletter No. 26: May-Aug/2008, SMERU Research Institute, Jakarta. 